\title{
Molecular Phylogeny of the Higher Category of Acrididae (Orthoptera: Acridoidea)
}

\author{
LIU Dian-feng ${ }^{1,2}$, DONG Zi-mei ${ }^{2}$, ZHANG Da-yu ${ }^{1}$, GU Yan-ze ${ }^{2}$, \\ GUO Pei-jun ${ }^{2}$, HAN Rui-hua ${ }^{2}$, JIANG Guo-fang ${ }^{1, *}$ \\ (1. Jiangsu Key Laboratory for Bioresource Technology, College of Life Sciences, Nanjing Normal University, Nanjing 210097, China; \\ 2. Department of Bioengineering and Agronomics, Puyang Vocational \& Technical Institute, Puyang 457000, China)
}

\begin{abstract}
The phylogenetic relationships among all taxa within the Acrididae (Orthoptera: Acridoidea) were largely unknown until now. In this study, to further investigations, 24 species of Acrididae from China were used as sample taxa. The sequence constitutions and variations were analyzed and the molecular phylogenetic trees were reconstructed based on the combined sequence data (795bp length in total) of 12S rDNA and 16S rDNA, using the grasshopper Pyrgomorpha conica of Pyrgomorphidae as the outgroup. The results showed that the rates of the two kinds of transitions are obviously much higher than that of the four kinds of transversions in these combined 12S+16S rDNA sequence data. The saturation of nucleotide substitutions happened in $12 \mathrm{~S}$ and $16 \mathrm{~S}$ rDNA sequence data. The molecular phylogenetic trees indicated that Oedipodinae is a monophyletic group and this subfamily is a natural one, but Catantopinae and Acridinae are non-monophyletic. Oedipodnae is a relatively primitive group within the Acrididae, whereas the Oxyinae may have diverged later than Oedipodinae, but earlier than most other species of Acridide.
\end{abstract}

Key words: Phylogeny; Acrididae; 16S rDNA; 12S rDNA

\section{蝗科高级阶元的分子系统发育}

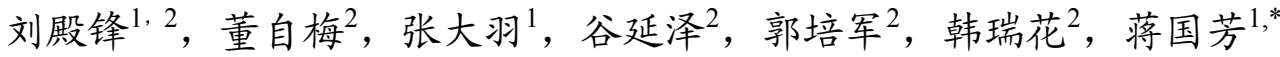 \\ （1.南京师范大学 生命科学学院，江苏省生物资源技术重点实验室，南京 210046; \\ 2. 誉阳职业技术学院 生物工程与农业经济系, 兴阳 457000)
}

摘要: 迄今，蝗科内各分类阶元之间的系统发生关系大部分是未知的。本文用来自中国 24 种蝗科昆虫的 $12 \mathrm{~S}$ rDNA 和 $16 \mathrm{~S}$ rDNA 2 个基因的联合序列(共 $795 \mathrm{bp}$ )数据, 以雉头蝗科的雉头蝗(Pyrgomorpha conica)为外群, 重 建了分子系统树。研究结果表明, 在 $12 \mathrm{~S} \mathrm{rDNA}$ 与 $16 \mathrm{~S} \mathrm{rDNA}$ 组成的联合数据中, 转换的替代速率明显比颠换的 替代速率高得多，核酸的替代已经发生了饱和。分子系统树表明：斑翅蝗亚科是一单系群，该亚科是一个合法的 亚科, 但斑腿蝗亚科和蝗亚科都不是单系群; 斑翅蝗亚科在蝗科内是一个相对原始的类群, 而稻蝗亚科比斑翅蝗 亚科相对进化，比蝗科的其他亚科的种类相对原始。

关健词: 系统发育; 蝗科; $16 \mathrm{~S}$ rDNA; $12 \mathrm{~S} \mathrm{rDNA}$

中图分类号: Q969.26+5.2; Q951.3 文献标识码：A＼cjkstart文章编号：0254-5853 (2007) 06-0585-07

The Acrididae belongs to the superfamily Acridoidea of Orthoptera and is the largest family in the Acridoidea. So far, more than 800 species of Acrididae have been described in China (Xia, 1994) and Chinese taxonomists have widely adopted Xia's taxonomic system of Acridoidea. In this system, Acridoidea was divided into eight families: Pamphagidae, Chrotogonidae, Pyrgomorphidae, Catantopidae, Oedipodidae, Arcypteridae, Gomphoceridae and Acrididae (Zheng, 1993; Xia, 1994). However, this system is very different from the

Received date: 2008-02-25; Accepted date: 2008-09-18

Fundation item: Supported by National Natural Science Foundation of China (30160015)

收稿日期: 2008-02-25; 接收日期: 2008-09-18

*通讯作者(Corresponding author), E-mail: cnjgf1208@163.com.

第一作者简介: 刘殿锋, 男, 讲师, 研究方向为昆虫分子系统学, Email: hn_1df@126.com 
international taxonomic system, the Orthoptera Species File (OSF) (http://osf2.orthoptera.org/HomePage.aspx), in which the superfamily Pyrgomorphoidea includes only one family Pyrgomorphidae, and the superfamily Acridoidea was divided into 11 families, including the Acrididae,Charilaidae, Dericorythidae, Lathiceridae, Lentulidae, Lithidiidae, Ommexechidae, Pamphagidae, Pyrgacrididae, Romaleidae and Tristiridae. The members of the Catantopidae, Oedipodidae, Arcypteridae, Gomphoceridae and Acrididae in Xia's system belong to the same family as the Acrididae in the international system (Kevan, 1982; Flook \& Rowell, 1997; Eades, 2007; Xia, 1994). In addition, it had been proven by $18 S$ rDNA (Liu $\&$ Jiang, 2005) and $16 S$ rDNA (Liu et al, 2005; Sun et al, 2006) that Catantopidae, Arcypteridae, Gomphoceridae and Acrididae were non-monophyletic. At the molecular level, Liu \& Jiang (2005) proposed that the above five families should be grouped into the family Acrididae in accordance with the international system.

What are the phylogenetic relationships of some taxa within the Acrididae? Is each subfamily within the Acrididae a monophyletic group? In this study, using Pyrgomorpha conica of Pyrgomorphidae as the outgroup, the molecular phylogenetic trees were reconstructed based upon the combined data of the 12S rDNA of 17 species (newly determined), the homologous sequences of 8 species (downloaded from GenBank) and $16 S$ rDNA of 25 species (downloaded from GenBank) in Acrididae grasshoppers to reassess their phylogenetic relationships, so as to further clarify these unresolved issues.

\section{Materials and methods}

\subsection{Samples and DNA extraction}

Seventeen species of grasshoppers from the Acrididae were collected from China (Tab. 1) and the samples were stored in absolute ethanol at $-20^{\circ} \mathrm{C}$. Total genomic DNA was extracted from the legs of single grasshoppers by using a simple proteinase K/SDS method. Tissue was ground and incubated in $0.02 \mathrm{~mol} / \mathrm{L}$ Tris- $\mathrm{HCl}(\mathrm{pH} 8), 0.01 \mathrm{~mol} / \mathrm{L}$ EDTA, $0.5 \%$ SDS, and 50 $\mathrm{mg} / \mathrm{mL}$ of Proteinase $\mathrm{K}$ overnight at $50^{\circ} \mathrm{C}$. This mixture was extracted with phenol/chloroform and DNA was precipitated with ethanol.

\subsection{PCR}

The primers, which were used for amplification in this study, were designed according to Simon et al (1994). The two primers used for the 12S rDNA fragment and the sequences were: SR-J-14233: 5'-AAGAGCGACGGGCGATGTGT-3' and SR-N-14588: 5'-AAACTAGGATTAGATACCCTATTAT-3'.

PCR reactions were performed in $30 \mu \mathrm{L}$ volume containing $10 \mathrm{mmol} / \mathrm{L}$ Tris $(\mathrm{pH} 8.3), 50 \mathrm{mmol} / \mathrm{L} \mathrm{KCl}$, $0.01 \%$ TritonX-100, $1.5 \mathrm{mmol} / \mathrm{L} \mathrm{MgCl}_{2}, 0.2 \mathrm{mmol} / \mathrm{L}$ each dNTP, $0.4 \mathrm{mmol} / \mathrm{L}$ primers, 1 unit of Taq-polymerase and $1 \mu \mathrm{L}$ template DNA (10-25 ng). Amplifications were performed under the following protocols: an initial denaturation of $5 \mathrm{~min}$ at $94^{\circ} \mathrm{C} ; 30 \mathrm{~s}$ at $94^{\circ} \mathrm{C}, 40 \mathrm{~s}$ at $48^{\circ} \mathrm{C}$, 30 s at $72^{\circ} \mathrm{C}, 30$ cycles; a final extension at $72^{\circ} \mathrm{C}$ for 10 min.

Products of successful PCR amplifications were purified using a GeneClean III kit (Anachem), following the protocol in the manual. Purified amplified product was sequenced by Shanghai United Gene Company.

\subsection{Data and phylogenetic analysis}

Tab. 1 List of specimens sampled and voucher numbers

\begin{tabular}{llll}
\hline \multicolumn{1}{c}{ Subfamily } & \multicolumn{1}{c}{ Species } & \multicolumn{1}{c}{ Locality } & Voucher number \\
\hline Spathosterninae & Spathosternum prasiniferum sinense & Fangchenggang, Guangxi & $\mathrm{H} 4232$ \\
& Spathosternum prasiniferum prasiniferum & Longzhou, Guangxi & $\mathrm{H} 4231$ \\
Cytacanthacridinae & Chondracris rosea rosea & Nanning, Guangxi & $\mathrm{H} 4651$ \\
& Patanga succincta & Fangchenggang, Guangxi & $\mathrm{H} 4681$ \\
Oxyinae & Oxya chinensis & Tianlin, Guangxi & $\mathrm{H} 4132$ \\
& Pseudoxya diminuta & Fangchenggang, Guangxi & $\mathrm{H} 4161$ \\
& Hieroglyphus banian & Longzhou, Guangxi & $\mathrm{H} 4222$ \\
Melanoplinae & Tonkinacris sinensis & Tianlin, Guangxi & $\mathrm{H} 4362$ \\
Catantopinae & Xenocatantops brachycerus & Tianlin, Guangxi & $\mathrm{H} 4811$ \\
& Xenocatantops humilis & Jinxiu, Guangxi & $\mathrm{H} 4822$ \\
& Apalacris varicornis & Longzhou, Guangxi & $\mathrm{H} 4751$ \\
& Traulia szetechuanensis & Tianlin, Guangxi & $\mathrm{H} 4691$ \\
Oedipodinae & Pternoscirta sauteri & Tian'e, Guangxi & $\mathrm{H} 5011$ \\
& Oedaleus manjius & Juesui, Guangxi & $\mathrm{H} 5191$ \\
& Trilophidia annulata & Longzhou, Guangxi & $\mathrm{H} 5281$ \\
Acridinae & Acrida willemsei & Chongzuo, Guangxi & $\mathrm{H} 8271$ \\
& Phlaeoba antennata & Chongzuo, Guangxi & $\mathrm{H} 8221$ \\
\hline
\end{tabular}


The $12 S$ rDNA fragments of 17 species from the Acrididae were sequenced in this study, and the $12 \mathrm{~S}$ rDNA fragments of 8 grasshoppers and 16S rDNA of 25 grasshoppers were downloaded from GenBank (Tab. 2). All species of the ingroup belonged to Acrididae and their samples were collected from China, and their sequences of both $12 \mathrm{~S}$ and $16 \mathrm{~S}$ rDNA were submitted by
Chinese researchers. The outgroup, Pyrgomorpha conica, from Swissland, belongs to the Pyrgomorphidae of the Pyrgomorphoidea, whose sequences of both $12 S$ and $16 S$ rDNA were sequenced by Flook et al (1999). In this paper, the classification of the Acridoidea was based on the Orthoptera Species File (OSF) (http://osf2.orthoptera. org/HomePage.aspx).

Tab. 2 Sequence data used in this study and GenBank accession numbers

\begin{tabular}{|c|c|c|c|c|c|}
\hline \multirow{2}{*}{ Subfamily } & \multirow{2}{*}{ Species } & \multicolumn{2}{|r|}{$16 \mathrm{~S}$} & \multicolumn{2}{|r|}{$12 \mathrm{~S}$} \\
\hline & & Accession No & Reference & Accession No & Reference \\
\hline \multirow[t]{2}{*}{ Spathosterninae } & $\begin{array}{l}\text { Spathosternum prasiniferum } \\
\text { sinense }\end{array}$ & DQ366828 & Lu and Huang, 2006 & AY247167 & This paper \\
\hline & $\begin{array}{l}\text { Spathosternum prasiniferum } \\
\text { prasiniferum }\end{array}$ & AY566259 & Liu et al, 2005 & AY247166 & This paper \\
\hline \multirow[t]{2}{*}{ Cytacanthacridinae } & Chondracris rosea rosea & AY566262 & Liu et al, 2005 & AY247184 & This paper \\
\hline & Patanga succincta & AY804006 & Liu et al, 2005 & AY247185 & This paper \\
\hline \multirow[t]{3}{*}{ Oxyinae } & Oxya chinensis & AY804002 & Liu et al, 2005 & AY247182 & This paper \\
\hline & Pseudoxya diminuta & AY566254 & Liu et al, 2005 & AY247170 & This paper \\
\hline & Hieroglyphus banian & AY804005 & Liu et al, 2005 & AY247173 & This paper \\
\hline Melanoplinae & Tonkinacris sinensis & AY566261 & Liu et al, 2005 & AY247186 & This paper \\
\hline \multirow[t]{4}{*}{ Catantopinae } & Xenocatantops brachycerus & AY804007 & Liu et al, 2005 & AY247177 & This paper \\
\hline & Xenocatantops humilis & AY566258 & Liu et al, 2005 & AY247178 & This paper \\
\hline & Apalacris varicornis & AY804000 & Liu et al, 2005 & AY247192 & This paper \\
\hline & Traulia szetechuanensis & AY803999 & Liu et al, 2005 & AY247174 & This paper \\
\hline \multirow[t]{5}{*}{ Oedipodinae } & Pternoscirta sauteri & AY856118 & Jiang and Liu, 2005 & AY247195 & This paper \\
\hline & Locusta migratoria manilensis & AY856117 & Jiang and Liu, 2005 & AY324452 & Ye et al, 2003 \\
\hline & Oedaleus asiaticus & AY856122 & Jiang and Liu, 2005 & AY560523 & Ye et al, 2004 \\
\hline & Oedaleus manjius & AY952313 & Lu and Huang, 2006 & AY247196 & This paper \\
\hline & Trilophidia annulata & AY856120 & Jiang and Liu, 2005 & AY247194 & This paper \\
\hline \multirow[t]{6}{*}{ Acridinae } & Ceracris fasciata szemaoensis & AY995328 & Jiang and Liu, 2006 & AY995320 & Jiang and Liu, 2006 \\
\hline & Ceracris fasciata fasciata & AY995327 & Jiang and Liu, 2006 & AY995319 & Jiang and Liu, 2006 \\
\hline & Ceracris nigricornis laeta & AY995325 & Jiang and Liu, 2006 & AY995322 & Jiang and Liu, 2006 \\
\hline & Rammeacris kiangsu & AY995330 & Jiang and Liu, 2006 & AY995316 & Jiang and Liu, 2006 \\
\hline & Acrida willemsei & DQ077181 & Sun et al, 2006 & AY247188 & This paper \\
\hline & Phlaeoba antennata & DQ077179 & Sun et al, 2006 & AY247187 & This paper \\
\hline Gomphocerinae & Chorthippus albonemus & AY995332 & Jiang and Liu, 2006 & AY995323 & Jiang and Liu, 2006 \\
\hline Pyrgormorphinae & Pyrgomorpha conica & Z97616 & Flook et al, 1999 & Z97600 & Flook et al, 1999 \\
\hline
\end{tabular}

All sequences were aligned using Clustal X1.83 (Thompson et al, 1997) with parameters set to default. Alignments were improved by comparison to the secondary structures and regions of uncertain alignment were omitted from subsequent analyses. Bases composition and sequence variability were examined using the software package MEGA4.0 (Tamura et al, 2007). Two different types of phylogenetic analyses were performed as below: the minimum evolution (ME) and the Bayesian inference. The former analyses were conducted using MEGA4.0 and the later inference was conducted using MrBayes3_0b4 (Huelsenbeck \& Ronquist, 2001). Trees saved below the burn-in generations were discarded, and a majority-rule consensus tree of the remains were calculated in Mrbayes3_0b4, providing posterior probabilities for each clade.

For the ME analysis, the Tamura-Nei's nucleotide substitution model was selected with pair-wise deletion of gaps, meanwhile, the interior branch test with 1000 replicates was used to assess the confidence that could be attached to the individual nodes. The MrBayes3_0b4 was run with the following specifications: The analysis was performed using GTR model including estimation site's invariants with a gamma distribution (invgamma). The Markov's chains were started from a random tree for 400,000 generations, sampling the Markov chains at intervals of 100 generations. Four chains were run simultaneously, 3 hot and one cold, with the initial 200 cycles discarded as burn-in.

\section{Results}




\subsection{Description of data}

After aligning, using Clustal X1.83, the lengths of $12 S$ and $16 S$ rDNA sequences including gaps were about $332 \mathrm{bp}$ and $463 \mathrm{bp}$ respectively, $795 \mathrm{bp}$ in total. The sequence data set of $12 \mathrm{~S}$ rDNA contained 159 variables and 100 parsimony-informative sites, and the sequence data set of $16 S$ rDNA contained 181 variables and 124 parsimony-informative sites. Across the two gene fragments, 340 sites were variable and 224 sites were parsimony-informative. The average values of intraspecific pair-wise sequence divergence was 0.118 in $12 S$ data set, 0.112 in $16 S$ data set and 0.113 in combined data set, respectively.

Nucleotide variation and substitution patterns were examined using the software package MEGA 4.0. The average value $T_{S} / T_{V}$ was 1.415 in $12 S$ rDNA sequence data, 0.876 in $16 S$ rDNA sequence data, and 1.046 in combined sequence data set. $\mathrm{T}_{\mathrm{V}}$ was almost identical to $\mathrm{T}_{\mathrm{S}}$ in combined data. The nucleotide compositions of the sequences were similar, and had a high $\mathrm{A}+\mathrm{T}$ content both in $12 S$ and $16 S$ sequences. The $\mathrm{A}+\mathrm{T}$ contents was $71.4 \%$ and the $\mathrm{G}+\mathrm{C}$ contents was $28.6 \%$ in the combined data set. Due to the existence of many differences in base composition, the Tamura-Nei's substitution model, which considers not only $\mathrm{T}_{\mathrm{S}} / \mathrm{T}_{\mathrm{V}}$ but also base composition, was selected in this analysis.

The nucleotide substitution model parameter from Bayesian analysis is shown in Tab. 3. Bayesian analysis indicated that two kinds of transition rates were much higher than transvertions.

\subsection{Phylogenetic relationships}

Fig.1-2 present the phylogenies recovered under minimum evolution and Bayesian analysis, respectively. The values of interior branch test for some nodes in minimum evolution trees and the posterior probability values for some nodes in Bayesian tree were low. However, the topologies of the two trees were identical or very similar in most clusters. In ME and Bayesian trees, the species studied could be clearly classified into four clades as follows: Clade I included six species: Ac. willemsei (Acridinae), T. annulata (Oedipodinae), P. sauteri (Oedipodinae), Lo. migratoria manilensis (Oedipodinae), O. manjius (Oedipodinae) and $O$. asiaticus (Oedipodinae). Clade II contained three species: Ps. diminuta (Oxyinae), H. banian (Oxyinae) and Oxya chinensis (Oxyinae). Clade III consisted of only one species: Ap. varicornis (Catantopinae). Clade IV contained other species from this study. The relations between clusters were identical for Clade I, Clade II, and Clade III in ME and Bayesian trees, but topologies of Clade IV were different in the two trees. However, it was same between the two trees that $S$. prasiniferum sinense (Spathosterninae), S. prasiniferum prasiniferum (Spathosterninae) and To. sinensis (Melanoplinae) were clustered into one cluster, Xe. brachycerus (Catantopinae) and Xe. humilis (Catantopinae) were clustered into one cluster, Ch. rosea rosea (Cytacanthacridinae) and Pa. succincta (Cytacanthacridinae) clustered into one cluster, and $\mathrm{Ce}$. fasciata szemaoensis (Acridinae) and Ce. fasciata fasciata (Acridinae) clustered into one cluster. Moreover, these nodes were supported by high values of interior branch test (Fig. 1) or posterior probability values (Fig.2).

\section{Discussion}

\subsection{The saturation of sequence data and the reason for lower credibility on some nodes}

The results of the Bayesian analysis showed that the

Tab. 3 Nucleotide substitution model parameter estimates for Bayesian analysis

\begin{tabular}{lcccc}
\hline \multirow{2}{*}{ Parameter } & Mean & Variance & \multicolumn{2}{c}{$95 \%$ Credible Interval } \\
\cline { 4 - 5 } & & & Lower & Upper \\
\hline $\mathrm{TL}$ & 2.057086 & 0.043160 & 1.777000 & 2.361000 \\
$\mathrm{r}(\mathrm{G}<->\mathrm{T})$ & 1.000000 & 0.000000 & 1.000000 & 1.000000 \\
$\mathrm{r}(\mathrm{C}<->\mathrm{T})$ & 4.255614 & 0.983908 & 2.701429 & 6.483768 \\
$\mathrm{r}(\mathrm{C}<->\mathrm{G})$ & 0.057406 & 0.005037 & 0.010603 & 0.236028 \\
$\mathrm{r}(\mathrm{A}<->\mathrm{T})$ & 2.542484 & 0.327689 & 1.610336 & 3.805997 \\
$\mathrm{r}(\mathrm{A}<->\mathrm{G})$ & 8.291493 & 2.880768 & 5.536824 & 11.794261 \\
$\mathrm{r}(\mathrm{A}<->\mathrm{C})$ & 0.117518 & 0.008359 & 0.013451 & 0.317179 \\
pi(A) & 0.338327 & 0.000207 & 0.312000 & 0.366404 \\
pi(C) & 0.088537 & 0.000089 & 0.072088 & 0.105061 \\
pi(G) & 0.149924 & 0.000118 & 0.130286 & 0.171227 \\
pi(T) & 0.423212 & 0.000268 & 0.391838 & 0.452411 \\
alpha & 0.636878 & 0.023375 & 0.390973 & 0.976867 \\
pinvar & 0.310891 & 0.004560 & 0.153007 & 0.423776 \\
\hline
\end{tabular}




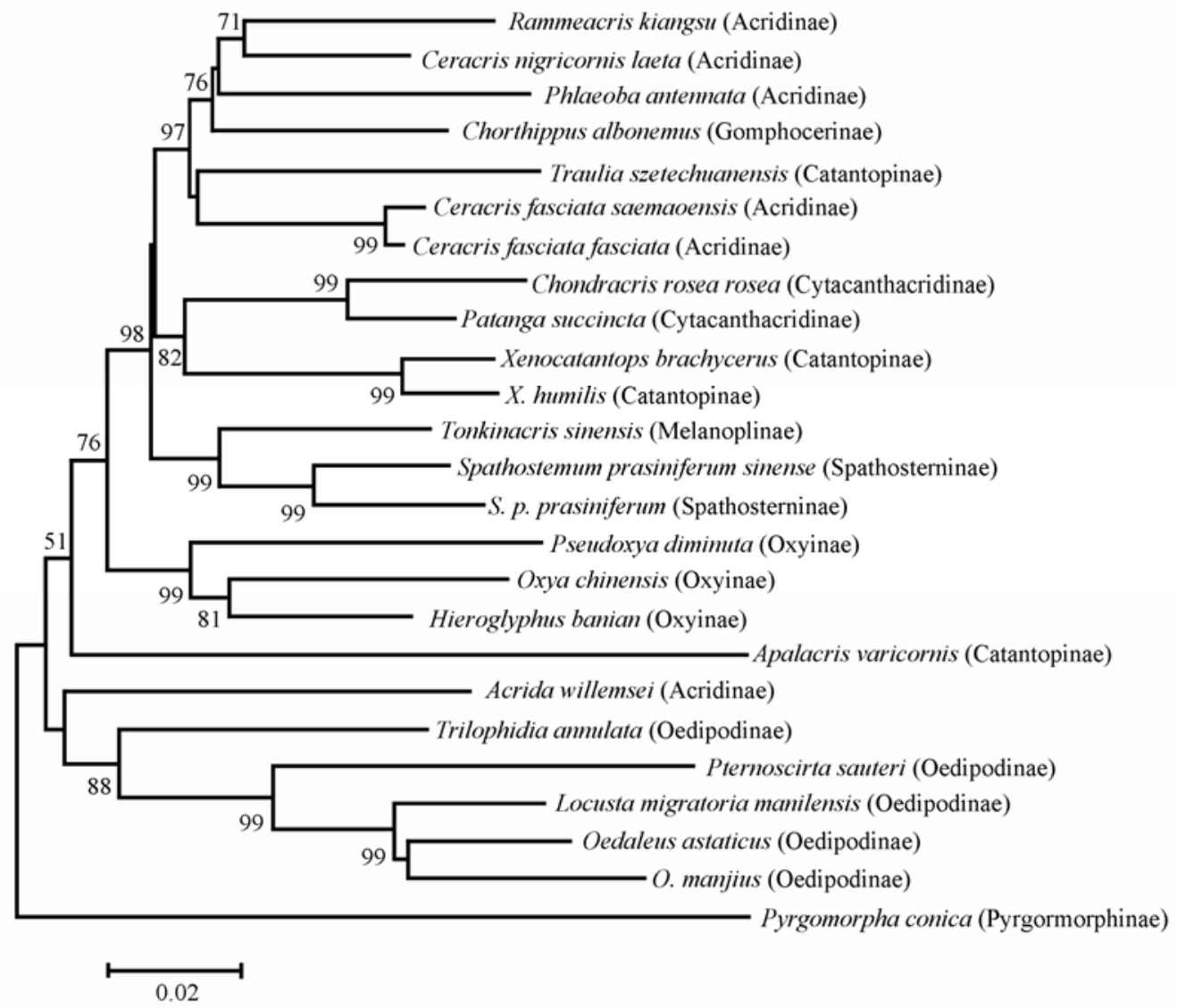

Fig. 1 Phylogram of ME tree reconstructed from combined 12S+16S data set Numbers on nodes correspond to values of interior branch test for 1000 replicates.

ratios of the two kinds of transitions were obviously much higher than the four kinds of transversions. However, the results from MEGA4.0 indicated that the average value of $\mathrm{T}_{\mathrm{S}} / \mathrm{T}_{\mathrm{V}}$ was 1.415 in $12 \mathrm{~S}$ rDNA sequence data, 0.876 in $16 \mathrm{~S}$ rDNA sequence data, and 1.046 in combined sequence data sets. The average value of $T_{S}$ was close to that of $T_{V}$ in the combined data set. We assume that the phenomenon results from two specifics. One is that saturation of nucleotide substitutions occur in $12 \mathrm{~S}$ and $16 \mathrm{~S}$ rDNA sequence data. Many scholars think that when the average value $T_{S} / T_{V}$ is smaller than 2 , saturation of nucleotide substitutions happen in sequences (Knight \& Mindell, 1993; Chen, 2003; Liu \& Jiang, 2005). The other reason is that the nucleotide compositions of the sequences have a high $\mathrm{A}+\mathrm{T}$ content both in $12 \mathrm{~S}$ and $16 \mathrm{~S}$ sequences. The high $\mathrm{A}+\mathrm{T}$ content increases the frequency of transversion A-T, which leads to the average value of $\mathrm{T}_{\mathrm{S}} / \mathrm{T}_{\mathrm{V}}$ decreasing (Desalle, 1997; Liu \& Jiang, 2005).

The values of interior branch test on some of nodes of the minimum evolution tree were weak, and the posterior probability values for some nodes of the Bayesian tree were also relatively low. This result may be due to the high sequence divergence of $12 S$ and $16 S$ rDNA for some species studied. Cognato \& Sperling (2000) suggested that clades of closely related species $(<10 \%$ sequence divergence) commonly have high bootstrap values $(>90 \%)$, while clades with $>10 \%$ sequence divergence generally have lower bootstrap values $(<90 \%)$. In this study, the average value of intraspecific pair-wise sequence divergence is $11.8 \%$ in $12 \mathrm{~S}$ data set, $11.2 \%$ in $16 \mathrm{~S}$ and $11.3 \%$ in the combined data set, respectively, and these sequence divergences all are higher than $10 \%$.

\subsection{Taxonomic status of the Oedipodinae}

Most species of the Oedipodinae, as may be deduced from their common name, have brightly colored hind wings with a marginal or sub-marginal band, while a few species of this subfamily have clear hind wings. In this group of grasshoppers, the peg is absent between the front legs, and there is a median keel on pronotum. They make a crackling sound (crepitate) when they fly. The 


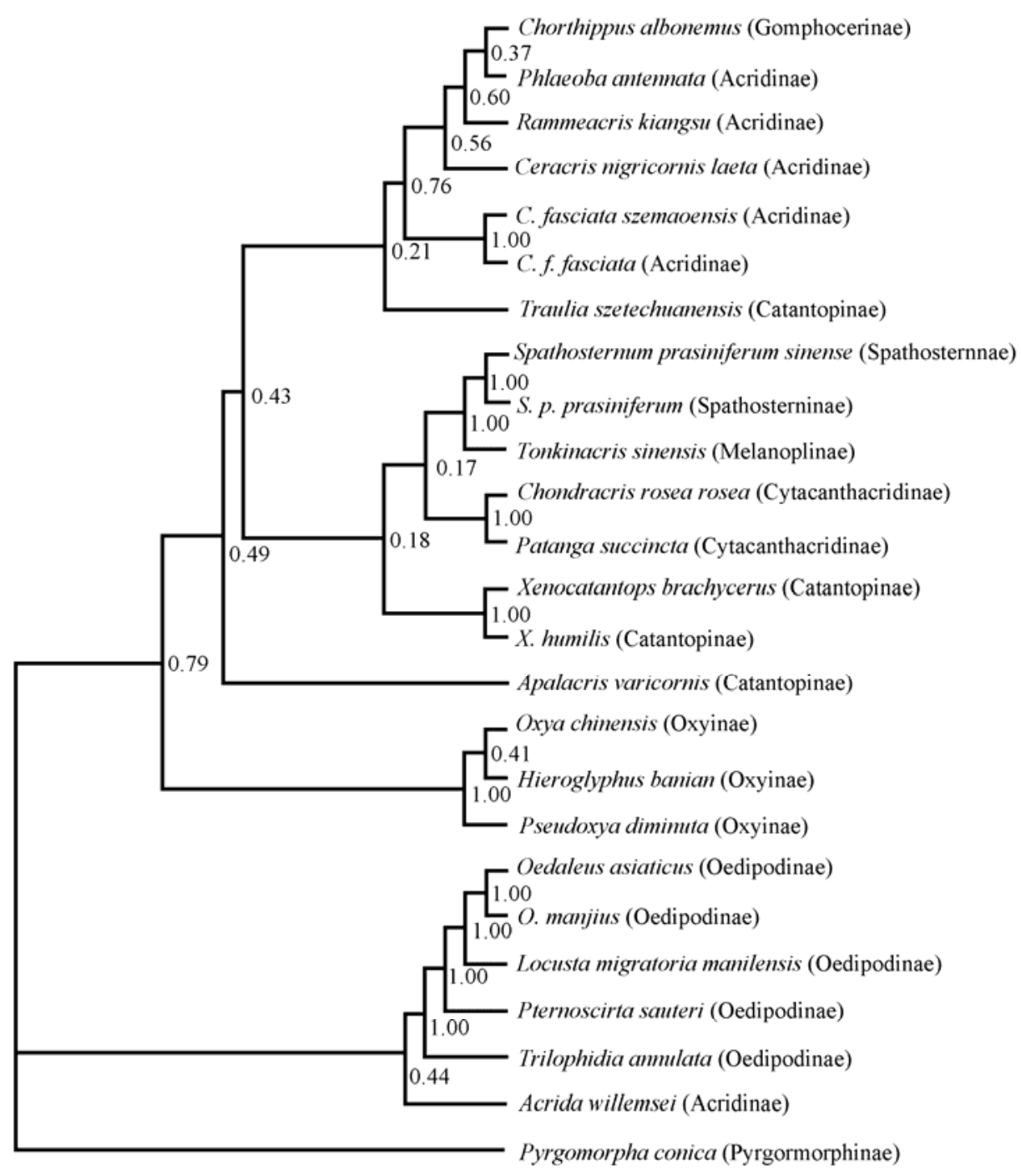

Fig. 2 Phylogram of Bayesian tree reconstructed from combined 12S+16S data set Numbers on nodes correspond to posterior probability values.

taxonomic status of Oedipodinae has changed several times. The synonym of this subfamily was Locustidae by Kirby (1825), and Oedipodidae by Walker (1871). In Xia's system (Xia, 1994), Oedipodinae is also upgraded to the taxonomic status of family. The Chinese scholars widely adopt Xia's taxonomy system about the Acridoidea. But in the OSF and NCBI taxonomy database, the group is classified as a subfamily in the Acrididae. Recently, based on the phylogenetic results of $18 S$ rDNA, Liu \& Jiang (2005) proposed that it was unreasonable to classify this group as a family and that the group should be placed as one of the subfamilies within Acrididae.
A taxon in a good taxonomic system should be a natural and monophyletic group. In our ME and Bayesian trees, T. annulata, P. sauteri, Lo. migratoria manilensis, $O$. manjius and $O$. asiaticus of the Oedipodinae were clustered into one clade. The results indicated that the subfamily is a monophyletic group, supporting Rowell \& Flook's (1998) view. Thus we suggest that the Oedipodnae should be taken as a legal subfamily.

\subsection{Monophylies of the subfamilies Catantopinae and Acridinae}

According to the OSF, the four species of grasshoppers, Xe. brachycerus, Xe. humilis, Apalacris 
varicornis and Tr. szetechuanensis, all belong to the subfamily Catantopinae. In this study, however, the four species of grasshoppers were not clustered together in the ME and Bayesian trees. The result agrees with the opinion of Rowell \& Flook (1998), from which Catantopinae is not a monophyletic but a polyphyletic group.

The Acridinae are silent and characterized by a slanted face and distinct hind wings (Yin \& Xia, 2003), usually found around marshes and wet meadows in small numbers and do little damage to vegetation. In our trees, the species of the subfamily Acridinae were not clustered as one clade, with the Acrida willemsei clustered together with the species of Oedipodinae. The results show that current Acridinae is non-monophyletic.

\section{References:}

Chen XF, Wang X, Yuan XD, Tang MQ, Li YX, Guo YM, Li QW. 2003. Sequence variation of mitochondrial cytochrome $b$ gene and phylogenetic relationships among twelve species of Charadriiformes[J]. Acta Genetica Sinica, 30 (5): 419-4241.

Cognato AI, Sperling FAH. 2000. Phylogeny of Ips DeGeer species (Coleoptera: Scolytidae) inferred from mitochondrial cytochrome oxidase I DNA sequence[J]. Molecular Phylogenetics and Evolution, 14(3): 445-460.

Desalle R, Freedman T, Prager EM. 1997. Tempo and mode of sequence evolution in mitochondrial DNA of Hawaiian Drosophila[J]. J Mol Evol, 26:157-164.

Flook PK, Klee S, Rowell CHF. 1999. Combined molecular analysis of the Orthoptera and implications for their higher systematics[J]. Syst Biol, 48(2): 233-253.

Flook PK, Rowell CHF. 1997. The Phylogeny of the Caelifera (Insecta, Orthoptera) as deduced from mtrRNA gene sequences[J]. Mol Phylogenet Evol, 8(1): 89-103.

Huelsenbeck JP, Ronquist F. 2001. MRBAYES: Bayesian inference of phylogenetic trees[J]. Bioinformatics, 17: 754-755.

Jiang GF, Zheng ZM. 1998. Grasshoppers and Locusts from Guangxi[M]. Guilin: Guangxi Normal University Press.

Kevan DKM. 1982. Orthoptera. In: Parker SP ed. Synopsis and Classification of Living Organisms[M]. New York: McGraw-Hill, 352-379.

Kirby, W. 1825. Some remarks on the nomenclature of the Gryllina of MacLeay, with the characters of a new genus in that tribe[J]. Zoological Journal, 1: 429-432.

Knight A, Mindell DP. 1993. Subsititions bias, weighting of DNA sequence evolution, and the phylogenetic positions of Fea's viper[J]. Syst Biol, 42(1): 18-31.

Tamura K, Dudley J, Nei M, Kumar S. 2007. MEGA4: Molecular evolutionary genetics analysis (MEGA) software version 4.0[J]. Molecular Biology and Evolution, 24(8): 1596-1599.

Li HZ, Xia KL. 2006. Fauna Sinica, Insecta Vol. 43. Orthoptera: Acridoidea (Catantopidae) [M]. Beijing: Science Press.

Liu DF, Jiang GF. 2005. Molecular phylogenetic analysis of Acridoidea based on $18 \mathrm{~S}$ rDNA with a discussion on its taxonomic system[J].

\subsection{Phylogenetic relationships of the subfamilies of the Acrididae}

The fact that the Oedipodinae was at the base of phylogenetic trees (Figs.1-2), indicated that Oedipodnae is a relatively primitive group within the Acrididae. The subfamily Oxyinae is basal to the remaining subfamilies of Acrididae, and this result shows that the Oxyinae may have diverged later than Oedipodinae, but earlier than most other species of Acridide. Because of the differences in relationships among the Cytacanthacridinae, Catantopinae, Spathoterninae, Melanoplinae and Acridinae in both of the ME and Bayesian trees, their phylogenetic relationships require further investigation in the future.

Acta Entomologica Sinica, 48 (2): 232-241.

Liu DF , Jiang GF, Shi H, Sun ZL, Huo GM. 2005. Monophyly and the taxonomic status of subfamilies of the Catantopidae based on $16 \mathrm{~S}$ rDNA sequences[J]. Acta Entomologica Sinica, 48(5): 759-769.

Lu HM, Huang Y. 2006. Phylogenetic relationship of 16 Oedipodidae species (Insecta: Orthoptera) based on the $16 \mathrm{~S}$ rRNA gene sequences[J]. Insect Science, 13(2): 103-108.

Rowell CHF, Flook PK. 1998. Phylogeny of the Caelifera and the Orthoptera as derived from ribosomal gene sequences[J]. $J$ Orthoptera Research, 7 : 147-156.

Eades DC, Otte D, Naskrecki P. 2007. Orthoptera Species File Online. Version 2.0/3.1. <http://Orthoptera.SpeciesFile.org>.

Simon C, Frati F, Beckenbach A, Crespi B , Liu H, Flook P. 1994. Evolution, weighting and phylogenetic utility of mitochondrial gene sequences and a compilation of conserved PCR primers[J]. Ann Entomol Soc Am, 87: 651-7011.

Sun ZL, Jiang GF, Huo GM, Liu DF. 2006. A phylogenetic analysis of six genera of Acrididae and the monophyly of Acrididae in China using 16S rDNA sequences (Orthoptera, Acridoidea) [J]. Acta Zoologica Sinica, 52(2): 302-308.

Thompson JD, Gibson TJ, Plewniak F, Jeanmougin F, Higgins DG. 1997. The Clustal X windows interface: Flexible strategies for multiple sequence alignment aided by quality analysis tools[J]. Nucleic Acids Research, 24: 4876-4882.

Walker F. 1871. Catalogue of the Specimens of Dermaptera Saltatoria in the Collection of the British Museum [M]. Supplement: 102.

Xia KL. 1994. Fauna Sinica, Insecta Vol.4. Orthoptera: Acridoidea (Pamphagidae, Chrotogonidae, Pyrgomorphidae) [M]. Beijing: Science Press.

Yin XC, Xia KL. 2003. Fauna Sinica, Insecta Vol.32, Gomphoceridae and Acridoidea[M]. Beijing: Science Press.

Zheng ZM. 1993. Taxonomy of Grasshoppers[M]. Xi'an: Shanxi Normal University Press.

Zheng ZM, Xia KL. 1998. Fauna Sinica, Insecta Vol. 10. Orthoptera: Acridoidea (Oedipodidae and Arcypteridae) [M]. Beijing: Science Press. 